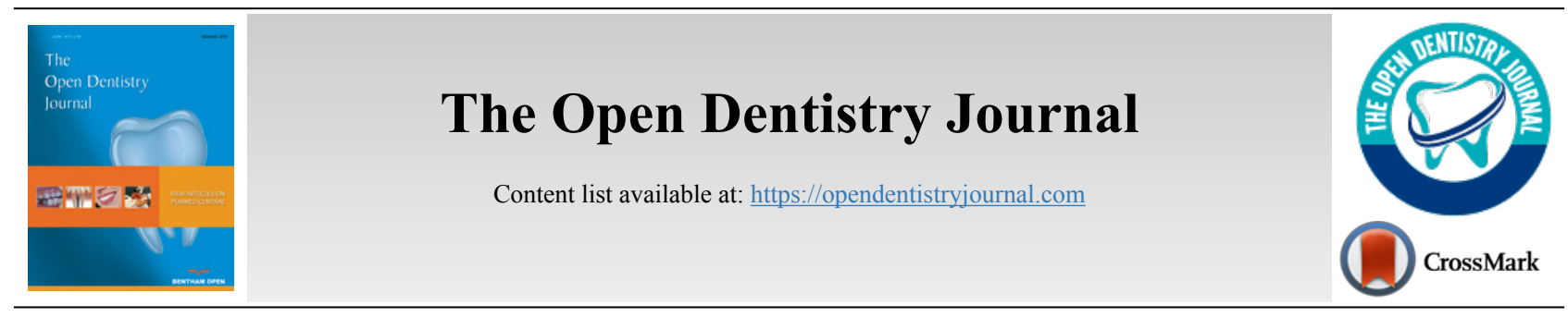

RESEARCH ARTICLE

\title{
Sella Turcica Bridging and its Association with Dental Anomalies
}

\author{
Divya Siddalingappa ${ }^{1, *}$, Arun S. Urala ${ }^{1}$, Kalyana C. Pentapati ${ }^{2}$, Ravindranath Vineetha ${ }^{3}$ and G. Lakshmi Prasad $^{4}$ \\ ${ }^{\prime}$ Department of Orthodontics, Manipal College of Dental Sciences, Manipal, Manipal Academy of Higher Education, Manipal, Karnataka, India \\ ${ }^{2}$ Department of Public Health Dentistry, Manipal College of Dental Sciences, Manipal, Manipal Academy of Higher Education, Manipal, Karnataka, \\ India \\ ${ }^{3}$ Department of Oral Medicine and Radiology, Manipal College of Dental Sciences, Manipal, Manipal Academy of Higher Education, Manipal, \\ Karnataka, India \\ ${ }^{4}$ Department of Neurosurgery, Kasturba Medical College, Manipal, Manipal Academy of Higher Education, Manipal, Karnataka, India
}

\begin{abstract}
:
Aim:

This study aimed to study the overall incidence of DA and its association with Sella Turcica bridging (STB).

Background:

Dental anomalies (DA) are associated with morphological changes in the Sella Turcica (ST).

Materials and Methods:

We retrieved the pretreatment patient records from March 2018 - March 2020 from the archives of the Orthodontics Department ( $\mathrm{n}=806$ ). We excluded the records with missing radiographs, concomitant cleft lip/ palate, history of surgical repair of cleft lip/ palate or any other craniofacial anomaly, history of trauma, and prior orthodontic treatment. A total of 676 patient records were included for initial screening, out of which 103 patients had DA (study group). A similar number of records $(\mathrm{n}=103)$ without any DA were randomly selected to constitute a control group. Determination of the extent of STB was done by calibrated and trained examiner. Age and sex were also recorded.

Results:

The incidence of DA was $15.24 \%$. The most common anomalies recorded were impacted canines $(6.8 \%)$ and hyperdontia (3.7\%), followed by agenesis $(2.1 \%)$ and others. Type III bridging in patients with DA was $22.3 \%$, while being $9.7 \%$ in the control group. Type II bridging was observed in $36.8 \%$ of patients with DA as compared to $29.1 \%$ in the control group. The presence of partial and complete STB in patients with dental anomalies was significantly higher than in the control group $(\mathrm{P}=0.006)$. The study group showed significant association with $\mathrm{STB}(\mathrm{OR}$ : $2.33 ; \mathrm{P}=0.003 ; 95 \% \mathrm{CI}: 1.33-4.11$ ) after adjusting for sex.

Conclusion:

The results of our study revealed a significant association between STB and DA.
\end{abstract}

Keywords: Bridging, Dental anomaly, Calcification, Interclinoid ligament, Pituitary fossa, Sella turcica.

\begin{tabular}{|l|l|l|l}
\hline Article History & Received: December 8, 2020 & Revised: June 10, 2021 & Accepted: June 20, 2021 \\
\hline
\end{tabular}

\section{INTRODUCTION}

Alterations in the Sella Turcica (ST) morphology are usually associated with an underlying syndrome or a malformation. Enlarged ST is seen in conditions like pituitary adenomas, mucoceles, meningiomas, primary hypothyroidism, empty sella syndrome, and Nelson syndrome. An abnormally

\footnotetext{
* Address correspondence to this author at the Department of Orthodontics, Manipal College of Dental Sciences, Manipal Academy of Higher Education, Manipal, Karnataka, India; Tel: +91- 963-215-6731,

E-mail: divya.s@manipal.edu
}

small ST, on the contrary, is a rare finding and is seen in primary hypopituitarism and Sheehan's syndrome [1].

Sella Turcica Bridging (STB) is the fusion of the Anterior Clinoid Process (ACP) and the Posterior Clinoid Process (PCP) due to calcification of the Interclinoid Ligament (ICL). It is an anatomical abnormality of the ST [2, 3]. The incidence of STB in the normal population ranges from $1.75-6 \%$ [4]. Conditions like basal cell carcinoma (Gorlin-Goltz) syndrome, Rieger syndrome, Axenfeld-Rieger syndrome, and severe craniofacial deviations are associated with STB $[3,5,6]$. 
Any developmental abnormalities in the tooth dimensions, morphology, position, number, and structure are common Dental Anomalies (DA). These DA can result from genetic factors such as defects in specific genes or environmental factors during the prenatal or postnatal periods [7]. To date, studies have shown an association of STB with only a few localized DA, such as impacted and palatal displacement of maxillary canines, agenesis $[2,8]$.

We aimed to evaluate the overall incidence of DA and its association with Sella Turcica Bridging (STB).

\section{MATERIALS AND METHODS}

All the pretreatment records were retrieved from March 2018- March 2020 from the archives of the Orthodontics Department $(\mathrm{n}=806)$. We excluded the records with missing radiographs, concomitant cleft lip/ palate, history of surgical repair of cleft lip/ palate or any other craniofacial anomaly, history of trauma, and prior orthodontic treatment. A single examiner screened 676 pretreatment diagnostic records (lateral cephalograms, panoramic, periapical, occlusal radiographs, dental casts, and intra-oral photographs) of patients. DA consequential to dental fluorosis and hypoplasia secondary to Amelogenesis Imperfecta and Dentinogenesis Imperfecta were excluded. Of the 676 records, 103 patients had DA and were categorized as a study group. A similar number of records $(n=103)$ without any DA were randomly selected to constitute a control group. Permission to conduct the study was obtained from the institutional ethics committee of Kasturba Hospital and Kasturba Medical College.

\subsection{Determination of the Extent of STB}

The pituitary fossa contour from the tip of Dorsum Sella (DS) to Tuberculum Sella (TS) was traced manually on an acetate paper using a $0.3 \mathrm{~mm}$ lead pencil in a dark room. A single trained examiner measured the length of the ST (distance between Tuberculum Sella and the tip of Dorsum Sella) and the greatest anteroposterior (AP) diameter (distance between Tuberculum Sella and the farthest point on the inner wall of the pituitary fossa) (Fig. 1) [2].

TS (Tuberculum Sella): The anterior boundary of sella turcica

DS (Dorsum Sella): The most posterior point on the internal contour of sella turcica

PS: The farthest point on the inner wall of the pituitary fossa

The extent of the STB on lateral cephalograms was assessed based on a standardized scoring scale as mentioned below [9]:

(1) Type I (no calcification of ICL): Length of the ST was greater than or equal to three-fourths of the A-P diameter (Fig. 2a) Type I sella turcica bridging.

(2) Type II (ICL partially calcified): Length of the ST was lesser than or equal to three-fourths of the A-P diameter (Fig. 2b) Type II sella turcica bridging.

(3) Type III (ICL ligament completely calcified): Diaphragma sella was radiographically visible (Fig. 2c) Type III sella turcica bridging.

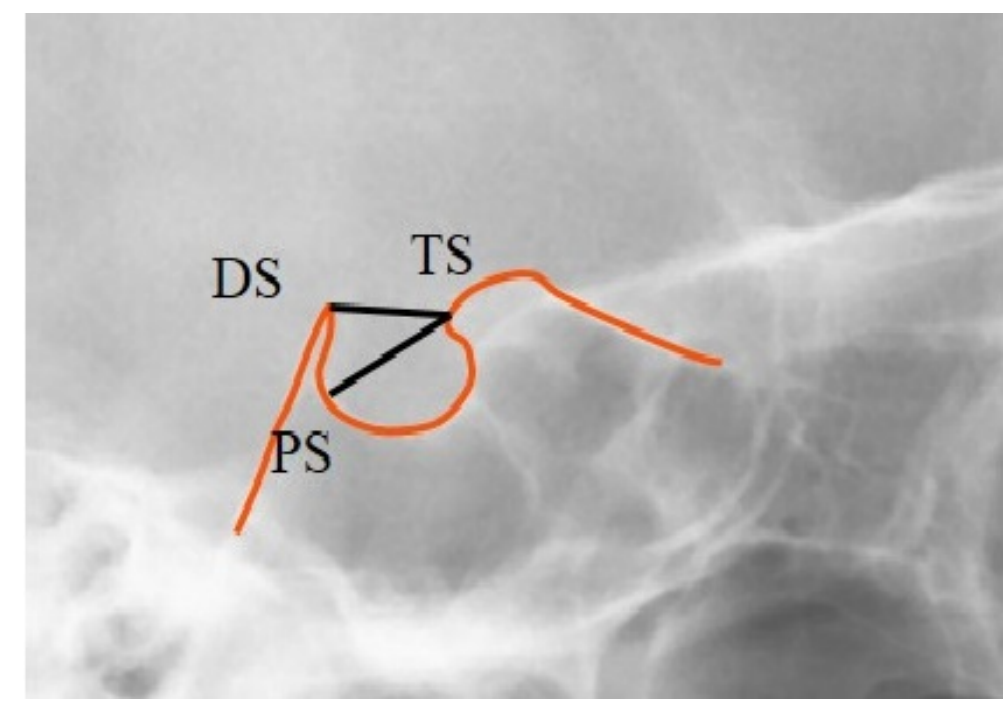

Fig. (1). Tracing of the sella turcica contour. 


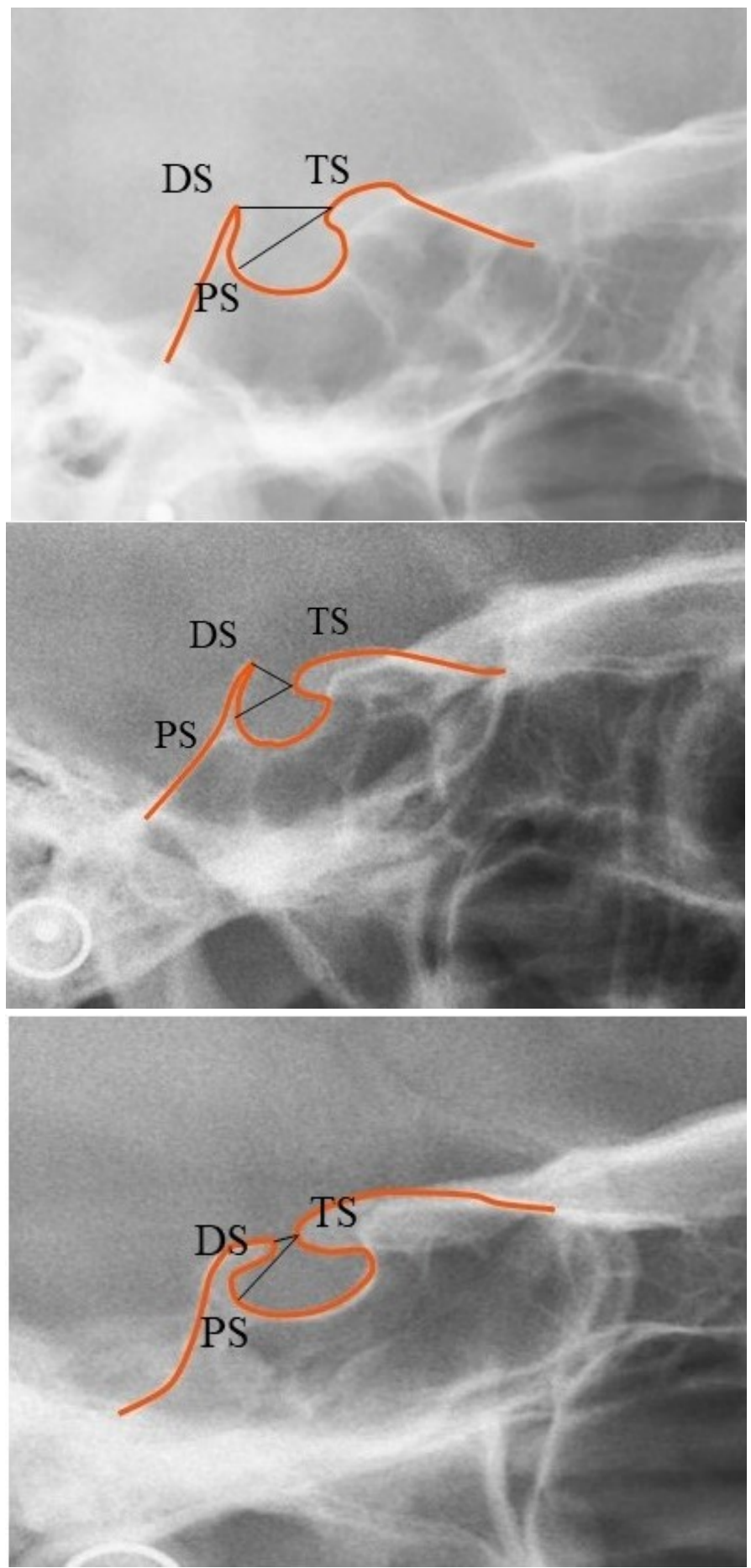

Fig. (2). Tracing of the sella turcica contour.

\subsection{Statistical Analysis}

Data were analyzed using SPSS version 20 (IBM Corp. Released 2011. IBM SPSS Statistics for Windows, Version 20.0. Armonk, NY: IBM Corp.). Descriptive statistics were applied for quantitative analysis. A p-value of $<0.05$ was considered statistically significant. Chi-square test was used for categorical variables, and Student t-test was used for continuous variables. Binary logistic regression analysis was done using STB as the independent variable and DA as the dependent variable. STB was dichotomized as absence or presence (partial or complete) of calcification. Significant variables in the bivariate analysis were adjusted. Model fit was assessed by Hosmer Lemeshow test.

\section{RESULTS}

There were 48 males and 55 females in the study group with a mean age of 17.81 years. There were 34 males and 69 females in the control group with a mean age of 18.07 years. Females were significantly more than males in the control 
group than the study group $(\mathrm{P}=0.046)$. No significant difference was seen in the mean age between the study and control group ( $\mathrm{P}=0.616)$ (Table 1).

Table 1. Distribution of age and sex in study and control group.

\begin{tabular}{|c|c|c|c|}
\hline & $\begin{array}{c}\text { Study Group } \\
\text { N(\%) }\end{array}$ & $\begin{array}{c}\text { Control Group } \\
\mathbf{N}(\%)\end{array}$ & P-value \\
\hline Sex & & & \\
\hline Male & $48(46.6)$ & $34(33)$ & \multirow{2}{*}{0.046} \\
\cline { 1 - 3 } Female & $55(53.4)$ & $69(67)$ & \\
\hline Age & $17.81 \pm 3.71$ & $18.07 \pm 3.78$ & 0.616 \\
\hline
\end{tabular}

The total incidence of DA was $15.24 \%$. Impacted canine $(6.80 \%)$ was the common DA followed by hyperdontia $(3.70 \%)$, agenesis or congenitally missing $(2.07 \%)$, and microdontia or peg lateral $(1.04 \%)$. Others such as transposition $(0.59 \%)$, talons cusp $(0.59 \%)$, parastyle $(0.30 \%)$ and taurodontism $(0.15 \%)$ were rare anomalies (Table 2 ).

Table 2. Distribution of dental anomalies.

\begin{tabular}{|c|c|}
\hline Dental Anomaly & $\mathbf{N}(\%)$ \\
\hline Impacted canines & $46(6.8)$ \\
\hline Hyperdontia & $25(3.7)$ \\
\hline Agenesis & $14(2.07)$ \\
\hline Microdontia & $7(1.04)$ \\
\hline Transposition & $4(0.59)$ \\
\hline Talons cusp & $4(0.59)$ \\
\hline Parastyle & $2(0.3)$ \\
\hline Taurodontism & $1(0.15)$ \\
\hline
\end{tabular}

Among the study group, 23 (22.33\%) patients had type III bridging, 38 (36.89\%) patients had type II bridging, and 42 $(40.78 \%)$ patients had type I bridging. In the control group, 10 (9.71\%) patients had type III bridging, 30 (29.13\%) patients had type II bridging, and $63(61.17 \%)$ patients had type I bridging. The presence of partial and complete STB in patients with dental anomalies was significantly higher than in the control group ( $\mathrm{P}=0.006)$ (Table 3).

Table 3. Association of Sella turcica bridging in study and control groups.

\begin{tabular}{|c|c|c|c|}
\hline & $\begin{array}{c}\text { Study Group } \\
\text { N (\%) }\end{array}$ & $\begin{array}{c}\text { Control Group } \\
\text { N (\%) }\end{array}$ & \multirow{2}{*}{ P-value } \\
\cline { 1 - 3 } Bridging & & & \multirow{2}{*}{0.006} \\
\cline { 1 - 3 } Type I & $42(40.78)$ & $63(61.17)$ & \\
\cline { 1 - 3 } Type II & $38(36.89)$ & $30(29.13)$ & \\
\cline { 1 - 3 } Type III & $23(22.33)$ & $10(9.71)$ & \\
\hline
\end{tabular}

Binary logistic regression analysis was performed using STB as independent variables and dental anomalies as a dependent variable after adjusting for significant confounders (Sex). The study group showed significant association with STB (OR: 2.33 ; $\mathrm{P}=0.003$; 95\%CI: $1.33-4.11$ ) after adjusting for sex. The comparison of DS to TS and TS to PS measurements in different types of bridging is shown in Table $\mathbf{4}$ and the distribution of Sella turcica bridging according to the anomaly is shown in Table $\mathbf{5}$.
Table 4. Comparison of DS to TS and TS to PS measurements in different types of bridging.

\begin{tabular}{|c|c|c|c|}
\hline - & $\begin{array}{c}\text { Type 1 } \\
\text { Mean } \pm \text { SD }\end{array}$ & $\begin{array}{c}\text { Type 2 } \\
\text { Mean } \pm \text { SD }\end{array}$ & $\begin{array}{c}\text { Type 3 } \\
\text { Mean } \pm \text { SD }\end{array}$ \\
\hline DS to TS & $11.98 \pm 1.91$ & $5.55 \pm 1.1$ & $1.32 \pm 0.86$ \\
\hline TS to PS & $10.87 \pm 1.92$ & $11.66 \pm 1.4$ & $10.17 \pm 2.17$ \\
\hline
\end{tabular}

Table 5. Distribution of Sella turcica bridging according to the anomaly.

\begin{tabular}{|c|c|c|c|}
\hline - & Type 1 & Type 2 & Type 3 \\
\hline Hyperdontia & 14 & 6 & 5 \\
\hline Impacted canines & 18 & 19 & 9 \\
\hline Agenesis & 7 & 5 & 2 \\
\hline Microdontia & 2 & 2 & 3 \\
\hline Taurodontism & 0 & 0 & 1 \\
\hline Transposition & 0 & 3 & 1 \\
\hline Talons cusp & 0 & 3 & 1 \\
\hline Parastyle & 1 & 0 & 1 \\
\hline
\end{tabular}

\section{DISCUSSION}

ST is an essential cephalometric landmark in the midcranial region and houses the pituitary gland. This fossa is a saddle-shaped depression located in the sphenoid bone body and extends from the Tuberculum Sella to Dorsum Sella. It is defined anteriorly by the two anterior clinoid processes, which are medial projections of the posterior aspect of the lesser wing of the sphenoid bone, and posteriorly by two posterior clinoid processes, which are the lateral elevations of the Dorsum Sella.

Variations in size of the clinoid processes and the morphology have been reported, and the condition where there is a fusion of the anterior and posterior clinoid processes as a result of calcification of the ICL is called STB. The exact etiology of STB is still unclear. Previous studies reported a prenatal malformation involving the primordial cartilageassociation with the internal carotid artery path, ossification of the dura mater between the anterior and posterior clinoid processes, or a possible correlation with focal infections of the pituitary gland could be the possible reason for STB [10]. Furthermore, a clear differentiation between the real bony fusion and an overlap between the clinoid processes is difficult to identify.

The sellar point forms the geometric center of the pituitary fossa. Sella to nasion plane on the lateral cephalogram is commonly used to assess the anteroposterior position of the maxilla and mandible in relation to the skull base. STB seen on lateral cephalograms can serve as a diagnostic marker to predict the presence of DA [11]. The embryological origin of the two structures may explain the association between them. Embryologically, the ventral part of the sella, pituitary gland, and dental progenitor cells are neural crest cell derivatives. The region of the ST initiates the migration of these neural crest cells to the palatine, maxillary, and frontonasal developmental fields. Since the ST and the teeth share common embryologic origins, any alterations in the development of the former may result in bridging anomalies and simultaneously leading to DA. 
In our study, $15.24 \%$ had the presence of at least one DA. Our study included the entire spectrum of DA (Figs. 3-5). The results of our study demonstrated an increased frequency of type II and III STB (complete calcification) in patients with DA, which was statistically significant when compared to the control group. Previous studies reported the incidence of STB that ranged from 9.67 to 25.8 in patients with buccal and palatal impacted canines [11 - 13], 6 to $21.7 \%$ in patients with hyperdontia, $23.8 \%$ in patients with dental transposition [14], 15 and $18.7 \%$ in patients with agenesis [2], $13.3 \%$ in patients with highly placed canines [15] and $14.3 \%$ and $16.7 \%$ in patients with palatally displaced canines $[2,9]$.
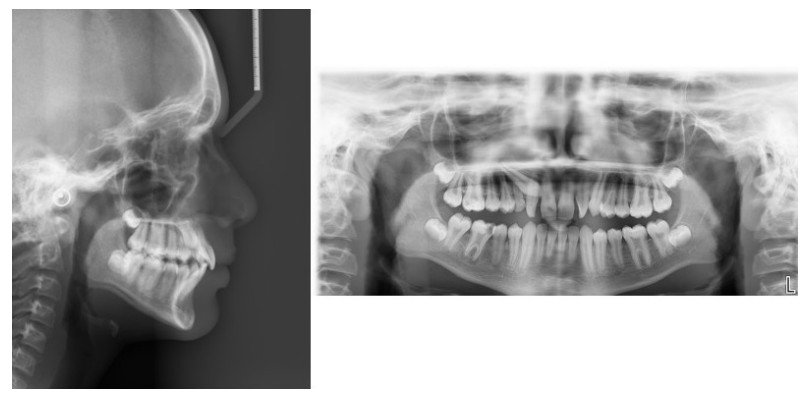

Fig. (3). Lateral cephalogram and orthopantomogram of a patient, with impacted canines.

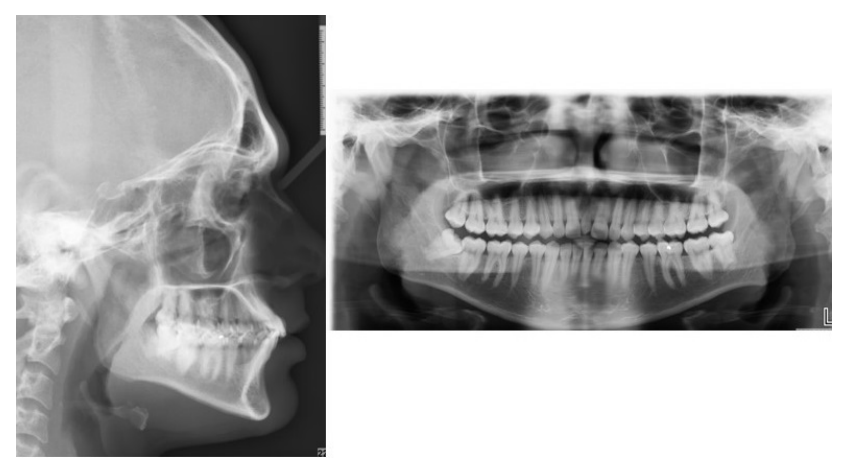

Fig. (4). Lateral cephalogram and orthopantomogram of a patient, with hyperdontia.

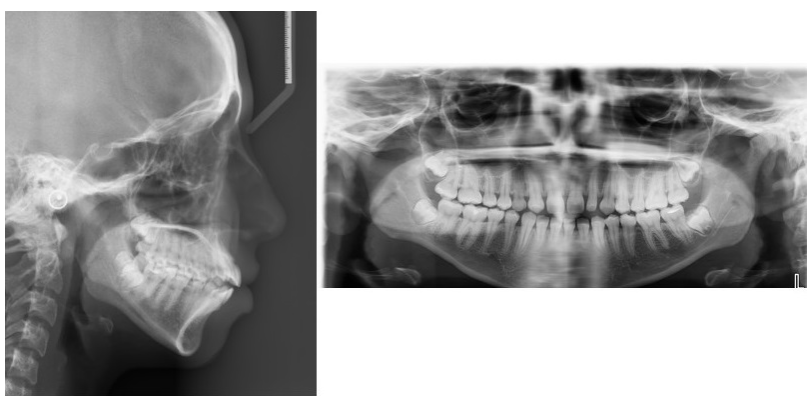

Fig. (5). Lateral cephalogram and orthopantomogram of a patient, with agenesis of maxillary right lateral incisor.

Subjects having severe craniofacial deviations requiring surgery reported a higher proportion of STB (18.6\%) [16]. Sundareswaran et al. reported an increased frequency of complete bridging in unilateral cleft lip and palate patients [17].
Multiple studies have reported higher incidences of bridging in patients requiring orthognathic surgeries. In a study involving Saudi patients, STB was noted in $4.83 \%$ in the orthodontic group compared to $6.19 \%$ in the orthognathic group of patients [18]. Similarly, Jones et al. reported a higher incidence of bridging in the combined surgical orthodontic group $(16.7 \%)$ as compared to the orthodontics-only group $(7.3 \%)$ [19].

There have also been reports suggesting that the type of malocclusion appears to play a potential role in the occurrence of sellar bridging. Few reported an increased frequency of STB in Class II and Class III skeletal patterns than a Class I skeletal pattern $[1,20]$. The reporting of STB also differs between direct anatomical studies and radiographic studies. This could be attributed to the superimposition of the overlapping clinoid processes on the lateral cephalograms. In a cadaveric study of 112 dry adult skull bones for the detection of STB, the authors noted that $8.04 \%$ of samples had evidence of bridging [21]. Our study reported a relatively higher percentage of bridging. Three-dimensional imaging such as cone beam computed tomography could have provided more precise and detailed information about the sella region.

\section{CONCLUSION}

Within the limits of this study, it can be concluded that

(1) The prevalence of sella turcica bridging might be positively associated with the occurrence of dental anomalies.

(2) The early appearance of Sella Turcica bridge on lateral cephalogram should alert the clinicians to the possible development of dental anomalies later in life.

\section{ETHICS APPROVAL AND CONSENT TO PARTICIPATE}

The institutional ethics committee of Kasturba Hospital and Kasturba Medical College, Manipal (IEC 858/2017) approved the protocol.

\section{HUMAN AND ANIMAL RIGHTS}

Not applicable.

\section{CONSENT FOR PUBLICATION}

Not applicable.

\section{AVAILABILITY OF DATA AND MATERIALS}

The data that support the findings of this study are available from the corresponding author [D.S] upon reasonable request.

\section{FUNDING}

None.

\section{CONFLICT OF INTEREST}

The authors declare no conflict of interest, financial or otherwise. 


\section{ACKNOWLEDGEMENTS}

Declared none.

\section{REFERENCES}

[1] Meyer-Marcotty P, Reuther T, Stellzig-Eisenhauer A. Bridging of the sella turcica in skeletal Class III subjects. Eur J Orthod 2010; 32(2): 148-53.

[http://dx.doi.org/10.1093/ejo/cjp081] [PMID: 19752019]

[2] Leonardi R, Barbato E, Vichi M, Caltabiano M. A sella turcica bridge in subjects with dental anomalies. Eur J Orthod 2006; 28(6): 580-5. [http://dx.doi.org/10.1093/ejo/cj1032] [PMID: 16954179]

[3] Koshino T, Konno T, Ohzeki T. Bone and joint manifestations of Rieger's syndrome: A report of a family. J Pediatr Orthop 1989; 9(2): 224-30.

[http://dx.doi.org/10.1097/01241398-198903000-00022] [PMID: 2494224]

[4] Busch W. Die Morphologie der Sella turcica und ihre Beziehungen zur Hypophyse. Virchows Arch Pathol Anat Physiol Klin Med 1951; 320(5): 437-58

[http://dx.doi.org/10.1007/BF00957474] [PMID: 14942993]

[5] McLachlan MS, Wright AD, Doyle FH. Plain film and tomographic assessment of the pituitary fossa in 140 acromegalic patients. $\mathrm{Br} \mathrm{J}$ Radiol 1970; 43(510): 360-9.

[http://dx.doi.org/10.1259/0007-1285-43-510-360] [PMID: 5427461]

[6] Meyer-Marcotty P, Weisschuh N, Dressler P, Hartmann J, StellzigEisenhauer A. Morphology of the sella turcica in Axenfeld-Rieger syndrome with PITX2 mutation. J Oral Pathol Med 2008; 37(8): 504-10.

[http://dx.doi.org/10.1111/j.1600-0714.2008.00650.x]

[PMID: $18331556]$

[7] Uslu O, Akcam MO, Evirgen S, Cebeci I. Prevalence of dental anomalies in various malocclusions. Am J Orthod Dentofacial Orthop 2009; 135(3): 328-35.

[http://dx.doi.org/10.1016/j.ajodo.2007.03.030] [PMID: 19268831]

[8] Baidas LF, Al-Kawari HM, Al-Obaidan Z, Al-Marhoon A, AlShahrani S. Association of sella turcica bridging with palatal canine impaction in skeletal Class I and Class II. Clin Cosmet Investig Dent 2018; 10: 179-87.

[http://dx.doi.org/10.2147/CCIDE.S161164] [PMID: 30154673]

[9] Haji Ghadimi M, Amini F, Hamedi S, Rakhshan V. Associations among sella turcica bridging, atlas arcuate foramen (ponticulus posticus) development, atlas posterior arch deficiency, and the occurrence of palatally displaced canine impaction. Am J Orthod Dentofacial Orthop 2017; 151(3): 513-20. [http://dx.doi.org/10.1016/j.ajodo.2016.08.024] [PMID: 28257736]

[10] Gibelli D, Cellina M, Gibelli S, et al. Sella turcica bridging and ossified carotico-clinoid ligament: Correlation with sex and age. Neuroradiol J 2018; 31(3): 299-304.

[http://dx.doi.org/10.1177/1971400917751036] [PMID: 29323624]

[11] Divya S, Urala A. Prasad GL, Pentapati K. Sella turcica bridging a diagnostic marker for impacted canines and supernumerary teeth. J Int Oral Health 2018; 10(2): 94-8.

[http://dx.doi.org/10.4103/jioh.jioh_276_17]

[12] Ali B, Shaikh A, Fida M. Association between sella turcica bridging and palatal canine impaction. Am J Orthod Dentofacial Orthop 2014; 146(4): 437-41.

[http://dx.doi.org/10.1016/j.ajodo.2014.06.010] [PMID: 25263146]

[13] Scribante A, Sfondrini MF, Cassani M, Fraticelli D, Beccari S, Gandini P. Sella turcica bridging and dental anomalies: Is there an association? Int J Paediatr Dent 2017; 27(6): 568-73.

[http://dx.doi.org/10.1111/ipd.12301] [PMID: 28387468]

[14] Leonardi R, Farella M, Cobourne MT. An association between sella turcica bridging and dental transposition. Eur J Orthod 2011; 33(4): 461-5.

[http://dx.doi.org/10.1093/ejo/cjq106] [PMID: 21212168]

[15] Suja AG, Ani S, Jose J, Sp P, Wane M. Morphology of Sella turcica in subjects with highly placed canines. Int J Bioassays 2015; 4(6): 3968-72.

[16] Becktor JP, Einersen S, Kjaer I. A sella turcica bridge in subjects with severe craniofacial deviations. Eur J Orthod 2000; 22(1): 69-74. [http://dx.doi.org/10.1093/ejo/22.1.69] [PMID: 10721247]

[17] Sundareswaran S, Nipun CA. Bridging the gap: Sella turcica in unilateral cleft lip and palate patients. Cleft Palate Craniofac J 2015; 52(5): 597-604

[http://dx.doi.org/10.1597/13-258] [PMID: 26317632]

[18] Abdel-Kader HM. Sella turcica bridges in orthodontic and orthognathic surgery patients. A retrospective cephalometric study. Aust Orthod J 2007; 23(1): 30-5.

[PMID: 17679532]

[19] Jones RM, Faqir A, Millett DT, Moos KF, McHugh S. Bridging and dimensions of sella turcica in subjects treated by surgical-orthodontic means or orthodontics only. Angle Orthod 2005; 75(5): 714-8. [PMID: 16279819]

[20] Shrestha GK, Pokharel PR, Gyawali R, Bhattarai B, Giri J. The morphology and bridging of the sella turcica in adult orthodontic patients. BMC Oral Health 2018; 18(1): 45.

[http://dx.doi.org/10.1186/s12903-018-0499-1] [PMID: 29548316]

[21] Kolagi S, Herur A, Patil G, Rairam GB. Complete sella turcica bridges prevalence and dimensions. J Anat Soc India 2011; 60(1): 22-5. [http://dx.doi.org/10.1016/S0003-2778(11)80005-5]

\section{(C) 2021 Siddalingappa et al.}

This is an open access article distributed under the terms of the Creative Commons Attribution 4.0 International Public License (CC-BY 4.0), a copy of which is available at: (https://creativecommons.org/licenses/by/4.0/legalcode). This license permits unrestricted use, distribution, and reproduction in any medium, provided the original author and source are credited. 